\title{
Identifikasi Bakteri Escherichia coli (E.coli) pada Air Minum di Rumah Makan dan Cafe di Kelurahan Jati serta Jati Baru Kota Padang
}

\author{
Wahyu Zikra ${ }^{1}$, Arni Amir $^{2}$, Andani Eka Putra ${ }^{3}$
}

\begin{abstract}
Abstrak
Air merupakan komponen yang sangat penting dalam kehidupan, seperti penggunanaan air sebagai air minum. Air minum juga digunakan oleh pedagang makanan. Tingginya kasus diare di Kelurahan Jati dan Jati Baru Kota Padang dapat dipicu penggunaan air minum yang tidak bersih. Tujuan penelitian ini adalah menentukan adanya kontaminasi oleh bakteri Escherichia coli dalam air minum pada rumah makan dan cafe di Kelurahan Jati dan Jati baru kota Padang. Penelitian ini bersifat deskriptif dengan perlakuan eksperimental terhadap 16 sampel air minum di Kelurahan Jati dan Jati Baru Kota Padang. Pengambilan sampel secara langsung dengan botol steril. Analisis data dengan menggunakan tabel (Most Probable Number) MPN 5-1-1 dan ditemukannya koloni bakteri Escherichia coli pada sampel air minum. Hasil penelitian ini didapatkan 13 sampel adanya kontaminasi air terhadap bakteri Coliform dengan indeks MPN didapatkan 3 sampel menunjukkan nilai indeks MPN yang tinggi yaitu: 2 sampel dengan indeks MPN 240/100 ml dan 1 sampel dengan indeks MPN 98/100 ml. Berdasarkan pemeriksaan Mac Conkey Agar ditemukan nya 13 sampel terdapat koloni bakteri Escherichia coli.
\end{abstract}

Kata kunci: Escherichia coli, MPN, Mac Conkey Agar

\begin{abstract}
Water is a very important component in life, such as the use of water as drinking water. Drinking water is also used by food traders. The high cases of diarrhea in Jati and Jati Baru urban village of Padang can be triggered by the use of unclean drinking water. The objective of this study was to determine the contamination of Escherichia coli bacteria in drinking water at restaurants and cafes in the new Jati and Jati urban village of Padang. This research was descriptive with experimental treatment on 16 samples of drinking water in Jati and Jati Baru urban village of Padang. Direct sampling with sterile bottles. Data analysis used table MPN 5-1-1 and the discovery of colony of bacteria Escherichia coli on drinking water sample. The result of this research was 13 samples of water contamination to Coliform bacteria with MPN index obtained 3 sample showed high MPN index value that is: 2 sample with MPN index 240/100 ml and 1 sample with MPN index 98/100 ml. Based on Mac Conkey examination In order to find 13 samples of the existing colony of bacteria Escherichia coli.
\end{abstract}

Keywords: Escherichia coli, MPN, Mac Conkey Agar

Affiliasi penulis: 1. Prodi Kedokteran Fakultas Kedokteran Universitas Andalas Padang (FK Unand), 2. Bagian Biologi FK Unand, 3. Bagian Biologi FK Unand

Korespondensi: Wahyu Zikra, Email: wahyu_zikra6@yahoo.com Telp: 085766240187

\section{PENDAHULUAN}

Air merupakan senyawa yang penting bagi kehidupan mahkluk hidup di bumi yang tidak dapat digantikan fungsi nya dengan senyawa lain. Penggunaan air terutama dan vital bagi kehidupan yaitu sebagai air minum. ${ }^{1}$ Salah satu pemeliharaan minuman untuk melindungi kesehatan masyarakat 
adalah pengawasan terhadap kualitas air minum, hal tersebut dikarenakan air minum merupakan salah satu komponen lingkungan yang mempunyai peranan cukup besar dalam kehidupan. Air dari sumber harus melalui proses pengolahan terlebih dahulu sampai air tersebut memenuhi syarat kesehatan, baik dari segi kualitas maupun kuantitasnya. $^{2}$

Kebutuhan nasional air di tingkat rumah tangga di Indonesia mencapai $2 \mathrm{~L}$ per hari bahkan bisa $100 \mathrm{~L}$ per hari. Menurut Riskesdas 2010 sumber air yang digunakan oleh rumah tangga di Indonesia sebagai air minum yaitu: sumur gali terlindung (24.7\%), air ledeng (14.2\%), sumur bor/pompa (14.0\%), dan air DAMIU (Depot Air Minum Isi Ulang) (13.8\%). Berdasarkan tempat tinggal baik di perkotaan maupun di pedesaan sumber utama air untuk minum cukup bervariasi, diperkotaan rumah tangga menggunakan air dari sumur bor/pompa (32,9\%), dan air ledeng/PDAM $(28,6)$, sedangkan dipedesaan lebih banyak menggunakan sumur gali telindung $(32,7){ }^{3}$

Kualitas air dapat ditinjau dari segi fisik, kimia, dan bakteriologis. Menurut Permenkes RI No.492/Menkes/Per/IV/2010 persyaratan secara fisik, air minum tidak berbau, tidak berasa, tidak bewarna, dan tidak keruh. Persyaratan bakteriologis air minum tidak boleh terdapat bakteri, sedangkan secara kimia air tidak boleh mengandung senyawa kimia beracun dan setiap zat terlarut dalam air memiliki batas tertentu yang diperbolehkan. ${ }^{4}$

Menurut Riskesdas 2013, pada umumnya $(94.1 \%)$ air minum rumah tangga di Indonesia termasuk dalam kategori baik (tidak keruh, tidak bewarna, tidak berasa, tidak berbusa, dan tidak berbau) namun demikian, masih terdapat rumah tangga dengan kualitas air minum keruh (3.3\%), berwarna $(1.6 \%)$, berasa $(2.6 \%)$, berbusa $(0.5 \%)$ dan berbau $(1.4 \%) .^{5}$

Penggunaan air minum tidak hanya di rumah tangga, air minum juga digunakan oleh pedagang makanan seperti tempat rumah makan dan cafe. Pedagang biasanya memperoleh air dari DAMIU dan air yang dimasak. Depot air minum sudah ada sejak tahun 2002, depot air itu sendiri adalah Industri yang melakukan proses pengolahan air baku menjadi air minum dan menjual langsung kepada pembeli. ${ }^{6}$

Banyak depot air yang belum terjamin, tidak sedikit yang ditemukan bakteri Escherichia coli (E.coli) dalam DAMIU. Penelitian di Kota Tangerang Selatan tahun 2012 terdapat 283 unit pengusaha depot air minum isi ulang dan baru 52 unit pengusaha yang mempunyai sertifikat Laik Hygiene Sanitasi depot air minum. ${ }^{7}$ Penelitian lain di Kota Padang tahun 2011 terdapat 604 pengusaha depot air minum, 120 diantaranya memenuhi Keputusan Menteri Perindustrian dan Perdagangan (Kepmenperindag) No.651 Tahun $2004 .^{8}$

Rerata masyakarat perkotaan menggunakan air yang berasal dari PDAM (Perusahaan Daerah Air Minum). Masalah umum yang dihadapi adalah konsumsi air yang terus meningkat sejalan dengan pertumbuhan penduduk, sedangkan debit air tetap terbatas, hal ini akan berdampak kepada penurunan kualitas air bersih baik secara kualitas maupun kuantitas.

Berdasarkan data kependudukan, kecepatan pertambahan jumlah penduduk Indonesia adalah 2.3\% per tahun, artinya apabila percepatan pertambahan penduduk tersebut tidak dikurangi, maka setiap 30 tahun jumlah penduduk akan menjadi dua kali lipat. ${ }^{9}$ Tahun 2016, layanan PDAM di Kota Padang berjumlah 106907, dimana 99771 digunakan oleh rumah tangga, niaga 5150 , sosial 1127 , dan instansi pemerintah $857 .^{10}$

Masalah utama adalah kualitas air minum yang buruk akan berdampak kepada kesehatan. Air dapat menjadi penyebaran penyakit tertentu seperti diare. Air merupakan media yang baik untuk kehidupan bakteri patogen contohnya bakteri Escherichia coli. ${ }^{711}$ Penelitian pada depot air minum, didapatkan hasil penelitian 9/9 terdapat cemaran mikroba yaitu $1.0 \times 10^{2} .^{12}$ Kecamatan Bungus Padang ditemukan 3/5 sampel terdapat bakteri Escherichia coli. ${ }^{13}$

Escherichia coli terdapat di usus manusia atau hewan yang akan dikeluarkan melalui tinja. Mikroorganisme patogen yang terkandung dalam tinja dapat menularkan beragam penyakit bila masuk 
tubuh manusia, dalam satu gram tinja dapat mengandung satu miliar partikel virus infektif yang mampu bertahan hidup selama beberapa minggu pada suhu dibawah $10^{\circ} \mathrm{C}$. Terdapat empat mikroorganisme patogen yang terkandung dalam tinja yaitu: virus, protozoa, cacing dan bakteri yang umumnya banyak ditemukan adalah bakteri jenis Escherichia coli.

Bakteri Escherichia coli termasuk bakteri yang dapat menyebabkan keluhan diare. Penyakit ini adalah salah satu dari banyak penyakit lain yang dapat disebabkan oleh buruknya kualitas air minum secara mikrobiologis. ${ }^{12}$ Menurut data Dinas Kesehatan Kota Padang tahun 2014, diare termasuk dalam sepuluh penyakit yang banyak terjadi di kota Padang. Tercatat kasus diare di kota Padang Timur yaitu sekitar 80.272 kasus pada tahun 2014 dimana 39.975 kasus dialami laki-laki dan 40.297 kasus pada perempuan. Hal ini dimungkinkan terjadi salah satunya akibat kualitas air minum kurang yang baik banyak dikonsumsi masyarakat sekitar. ${ }^{13}$

Berdasarkan penjelasan di atas, perlu untuk dilakukan penelitian terhadap identifikasi bakteri Escherichia Coli pada air minum di rumah makan dan cafe di kelurahan Jati dan Jati Baru kota Padang. Penelitian ini juga dikarenakan pada daerah Padang Timur banyak ditemukan kasus diare dan tempat kuliner. Diharapkan dengan adanya penelitian ini dapat berperan dalam penurunan angka penyebaran penyakit melalui air (waterbone disease).

Penelitian ini dilakukan dengan tujuan untuk mengetahui kontaminasi oleh bakteri Escherichia coli di air minum pada rumah makan dan cafe di Kelurahan Jati dan Jati baru kota Padang.

\section{METODE}

Penelitian ini bersifat deskriptif yang dilakukan di UPTD Balai Laboratorium Kesehatan Provinsi Sumatra Barat dari November 2017 sampai Februari 2018. Sampel pada penelitian ini adalah air minum pada rumah makan dan cafe di kelurahan Jati serta Jati Baru Kota Padang. Populasi didapatkan 16 sampel dengan menggunakan Total Sampling.
Metode penelitian dilakukan menggunakan Uji Most Probable Number (MPN) dan dilanjutkan dengan Mac Conkey Agar. Hasil yang didapatkan diolah secara manual yang diolah dalam bentuk tabel.

\section{HASIL}

\section{Hasil Pemeriksaan Air Minum dengan Uji MPN Test}

Ada 13 sampel (81.25\%) dari 16 sampel yang menunujukkan indeks MPN yang positif. Terdapat 3 sampel dengan indeks MPN tertinggi yaitu 115/100 ml sampel sebanyak 2 sampel dan 96/100 ml sampel sebanyak 1 sampel. Indeks MPN terendah yaitu 2.2/100 ml sampel. Sebanyak 3 sampel air minum dengan nilai indeks MPN 0/100 ml sampel. Indeks MPN didapatkan (62.5\%) dikategorikan air minum yang kurang bagus, (12.5\%) dikategori amat buruk, (6.25\%) buruk, dan (18.75) dikategorikan sebagai air minum yang bagus.

\section{Identifikasi bakteri Escherichia coli dalam Air Minum dengan Mac Conkey Agar}

Didapatkan 13 (100\%) dari 13 sampel yang menunjukkan pertumbuhan koloni bakteri merah muda. Dari isolasi pertumbuhan Mac Conkey Agar koloni yang tumbuh adalah Escherichia coli.

Tabel 1. Hasil uji Mac Conkey agar

\begin{tabular}{ccc}
\hline No & Escherichia coli & Jumlah Sampel \\
\hline 1 & Positif & 13 \\
2 & Negatif & 0 \\
\hline Total & 13 & \\
\hline
\end{tabular}

\section{Perbandingan Rumah dan Cafe Ditemukan Bakteri Escherichia coli}

Perbandingan rumah dan cafe yang positif ditemukan koloni Escherichia coli di Kelurahan Jati dan Jati Baru Kota Padang adalah Rumah Makan $(62.5 \%)$ dan Cafe (18.75\%), sedangkan untuk sumber air minum yang dijadikan untuk sampel didapatkan perbandingan yang positif koloni Escherichia coli yaitu Air Galon (25\%) dan Air Dimasak (56.25\%). 


\section{PEMBAHASAN}

Hasil pemeriksaan 16 sampel air minum menunjukkan bahwa $81.25 \%$ air minum pada rumah makan dan cafe di Kelurahan Jati dan Jati Baru Kota Padang mengandung bakteri Coliform yang tidak memenuhi syarat bakteriologis. Sesuai dengan peraturan pemerintah yang telah ditetapkan pada peraturan pemerintah Kepmenkes RI No.492/Menkes/ PER/IV/2010 yaitu air yang digunakan dalam air minum jumlah bakteri Escherichia coli harus 0/100 ml sampel.

Hasil indeks MPN tertinggi yaitu 2 sampel 115/100 ml dan 96/100 ml, menandakan air minum tersebut telah terkontaminasi dengan bakteri Coliform dan menigkatnya risiko bakteri patogen lain. Semakin tinggi tingkat kontaminasi bakteri Coliform semakin tinggi pula risiko kehadiran bakteri patogen lain. Sebaliknya, semakin sedikit kandungan bakteri Coliform semakin baik pula kualitas bakteriologis air minum. $^{14}$

Adanya bakteri Coliform di dalam air minum mengidentifikasikan air minum tersebut telah terkontaminasi dengan polusi kotoran. ${ }^{15} \mathrm{Hal}$ ini tidak sesuai dengan opini dan anggapan masyarakat bahwa air minum yang dimasak dirumah makan dan cafe lebih higienis dibandingkan dengan air galon karena sistem pemasakan air minum tersebut tidak semua air yang dimasak, mungkin air yang dimasak dicampurkan dengan air mentah supaya dapat mengurangi biaya pengeluaran dari rumah makan dan cafe tersebut.

Kontaminasi bakteri Coliform pada air minum dapat berasal dari berbagai sumber yaitu bahan baku yang digunakan dari air yang sudah tercemar, pendistribusian yang kurang baik serta tempat air yang tidak higienis. ${ }^{16}$ Kontaminasi air minum juga dapat bersumber dari juru masak tidak higienis, seperti tangan tidak higienis karena tidak dicuci, wadah penyimpanan yang tidak steril serta cara penyajian yang kurang higienis akan mempengaruhi higienitas dari air minum. ${ }^{17,18}$

Berdasarkan pemeriksaan dengan menggunakan Mac Conkey Agar didapatkan 13 (100\%) dari 13 sampel menunjukkan air minum pada rumah makan dan cafe di Kelurahan Jati dan Jati
Baru Kota Padang terkontaminasi oleh bakteri Escherichia coli. Hasil negatif pada 0 sampel. Escherichia coli yang terdapat pada air minum dapat disebabkan karena tidak higienis proses pembuatan air minum seperti sumber air minum yang tercemar, wadah yang digunakan tidak steril bahkan pekerja pemasak air minum ataupun air dari distributor perusahaan air minum yang tidak memerhatikan kebersihan. Lingkungan atau tepat pembuatan air minum, serta rendahnya pengetahuan serta kurangnya kesadaran tentang kebersihan akan menyebabkan air minum terkontaminasi oleh bakteri tersebut. ${ }^{19}$

Air minum yang telah terkontaminasi oleh bakteri Escherichia coli dapat membahayakan manusia karena Escherichia coli merupakan bakteri patogen bagi manusia yang dapat menyebabkan penyakit saluran cerna. ${ }^{20}$ Pada usus besar ditemukan Escherichia coli yang dapat bersifat patogen jika melebihi jumlah normal. Diare atau muntaber dapat menyebabkan wabah pada anak-anak. Strain tertentu juga dapat menyebabkan gastroenteritis. ${ }^{21}$ Jenis Coliform lain seperti Salmonella typhi juga dapat menyebabkan penyakit yaitu demam typoid. Bakteri ini masuk melalui mulut dan menyebar ke saluran pencernaan yang akan menimbulkan gejala seperti demam, lemah, sakit kepala, sakit perut, penurunan nafsu makan dan lain-lain. ${ }^{22}$

Membersihkan dan mengeringkan tangki air yang telah digunakan untuk pembuatan air minum secara berkala juga merupakan langkah yang baik dalam mencegah adanya akumulasi mikroorganisme. $^{23}$

\section{SIMPULAN}

Hampir semua air minum terkontaminasi oleh bakteri coliform, sehingga tidak memenuhi syarat bakteriologis dan tercemar oleh Escherichia coli.

\section{DAFTAR PUSTAKA}

1. Ball P. Water and life: seeking the solution. Nature. 2005. Agust 25;(1):1084-5.

2. Trihono. Kualitas air dan kesehatan masyarakat. hasil Riset Kesehatan Dasar (Riskesdas). Badan 
Penelitian Dan Pengembangan Kesehatan Kementrian Kesehatan RI.; 2010 Des 1: 351-77.

3. Departemen Kesehatan RI (Depkes RI). Kriteria air keperluan rumah tangga. hasil Riset Kesehatan Dasar (Riskesdas). Badan Penelitian Dan Pengembangan Kesehatan Kementrian Kesehatan RI. 2010.

4. Departemen Kesehatan RI (Depkes RI). Permenkes No/492/Menkes/Per/IV/2010 tentang: persyaratan kualitas air minum. Depkes RI; 2010.

5. Trihono. Kesehatan lingkungan: air minum dan sanitasi. Riset Kesehatan Dasar (Riskesdas). Badan Penelitian Dan Pengembangan Kesehatan Kementrian Kesehatan RI. 2013 Des 1:50-5.

6. Amrih P. Dua jam anda tahu: cara memastikan air yang anda minum bukan sumber penyakit. Home Improvement. 2005 Feb:9-39.

7. Dinas Kesehatan Tangerang Selatan. Sehatkan air minum isi ulang yang anda konsumsi. Dinas Kesehatan Tangerang Selatan; 2012.

8. Dinas Kesehatan Kota Padang. Depot air minum isi ulang di Kota Padang Per November. Dinas Kesehatan Kota Padang; 2011.

9. Siombo MR. Hukum lingkungan dan pelaksanaan pembangunan berkelanjutan di Indonesia. Jakarta: PT Gramedia Pustaka Utama; 2012.

10. Badan Pusat Statistik (BPS) Kota Padang: Kota Padang dalam angka tahun 2016. BPS Kota Padang.

11. Departemen Perindustrian dan Perdagangan RI. Keputusan menteri perindustrian dan perdagangan Republik Indonesia nomor 651 tahun 2004 tentang persyaratan teknis depot air minum dan perdagangannya. Departemen Perindustrian dan Perdagangan RI; 2004.

12. Suriawira U. Mikrobiologi air dan dasar-dasar pengolahan buangan secara biologis. 2008.

13. Dinas Kesehatan kota Padang. Profil Kesehatan Kota Padang. Dinas Kesehatan Kota Padang; 2015

14. Natalia LA, Bintari SH, Mustikaningtyas D. Kajian kualitas bakteriologis air minum isi ulang di kabupaten blora. Unnes Journal of Life Science. 2014;3(1):31-8.
15. Sopacua FC, Purwijantiningsih LME, Pranata S. Kandungan coliform dan klorin es batu di yogyakarta. Jurnal IImiah Biologi. 2013:9.

16. Food and Environmental Hygiene Departement (FEHD). The microbiological quality of edible ice from ice manufacturing plants and retail businesses in hongkong. Queensway: The Goverment of the Hong Kong Special Administrative Region. 2005.

17. Tantrakarnapa $K$, Makkaew $P$, Vatanasomboon $P$, Kengganpanich T. Association of sanitary condition and bacteriological quality of tube ice in ice plants in metropolitan bangkok, thailand. Environment Asia. 2010;3(1): 8-12.

18. Yanti E, Juita E, Farida. Studi tentang bakteri Escherichia coli dan logam berat dalam es batu yang digunakan pedagang di sepanjang pantai purus Kota Padang. Program Studi Pendidikan Geografi Sekolah Tinggi Keguruan dan IImu Pendidikan Sumatera Barat. 2014.

19. Elfidasari D, Saraswati AM, Nufadianti G, Samiah R, Setiowati V. Perbandingan kualitas es di lingkungan Universitas Al Azhar Indonesia dengan restoran fast food di daerah senayan dengan indikator jumlah Escherichia coli terlarut. Jurnal AlAhar Indonesia Seri Sains dan Teknologi. 2011;1(1):18-23.

20. Brooks GF, Carrol KC, Butel JS, Morse SA, Mietzner TA, Jawetz, et al. Medical microbiology. Edisi ke-25. EGC Medical Publisher; 2012.

21. Rahmaniar SA, Habib I. Perbandingan kualitas es batu di warung makan dengan restoran di DIY dengan indikator jumlah bakteri coliform dan Escherichia coli terlarut. Mutiara Medika. 2011;11(3):150-8.

22. Darmawati S. Keanekaragaman genetik Salmonella typhi. Jurnal Kesehatan. 2009;2(1): 27-33.

23. Chavasit V, Sirilaksanamanon K, Phithaksantayothin $\mathrm{P}$, Norapoompipat $\mathrm{Y}$, Parinsyasiri T. Measures for controlling safety of crushed ice and tube ice in developing country. Food Control. 2011;22:118-23. 